\title{
Factorial Design Evaluation of Some Experimental Factors for Phenols Oxidation using Crude Extracts from Jackfruit (Artocarpus integrifolia)
}

\author{
Antonio R. Cestari ${ }^{* a}$, Eunice F. S. Vieira ${ }^{a}$, Alisson J. P. Nascimento ${ }^{a}$, Marina M. Santos Filha ${ }^{a}$ \\ and Claudio Airoldi ${ }^{b}$ \\ ${ }^{a}$ Departamento de Química/CCET, Universidade Federal de Sergipe, CP 353, 49100-000, São Cristóvão - SE, Brazil \\ ${ }^{b}$ Instituto de Química, Universidade Estadual de Campinas, CP 6154, 13083-970, Campinas - SP, Brazil
}

\begin{abstract}
Este estudo apresenta algumas informações adicionais sobre a utilização alternativa do extrato bruto da jaca, em reações de oxidação seletivas de fenóis. Foram avaliados os substratos catecol, o-, me p- cresóis e pirogalol. Estudaram-se também os efeitos do pH, da concentração do tampão fosfato, bem como a utilização de alguns tipos de agentes extratores de biofenóis. Utilizando-se o procedimento convencional univariado, a atividade enzimática foi maior com o substrato catecol, em tampão fosfato $\mathrm{pH} 5,0$, de concentração $0,10 \mathrm{~mol} \mathrm{~L}^{-1}$ e agente comercial extrator de fenóis Polyclar SB-100 ${ }^{\circledR}$. Usando-se um planejamento fatorial, do tipo $2^{3}$, constatou-se que os melhores desempenhos catalíticos foram em pH 5,0 e concentração de tampão $0,050 \mathrm{~mol} \mathrm{~L}^{-1}$, para o substrato catecol. A variação no tipo de extrator não mostrou importância estatística. Pelo método multivariado, obtiveram-se os melhores resultados para a oxidação seletiva do catecol. Assim, conclui-se que para aumentar o desempenho catalítico do extrato, deve-se utilizar preferencialmente a metodologia multivariada.
\end{abstract}

This study presents some additional information on the alternative utilization of Jackfruit crude extracts in selective phenol oxidation reactions, using catechol and the o-, m- e p- cresols and pyrogallol substracts. The effects of $\mathrm{pH}$, concentration of phosphate buffer and kinds of natural phenol extractors are evaluated. By using the conventional univariate procedure, the best enzymatic activities were obtained with the catechol substract, phosphate buffer $(\mathrm{pH} 5.0)$ at a concentration $0.10 \mathrm{~mol} \mathrm{~L}^{-1}$, and the commercial polymer Polyclar SB-100 ${ }^{\circledR}$ as natural phenol extractor. Using a full $2^{3}$ factorial design the best catalytic results were obtained by employing phosphate buffer at $\mathrm{pH} 5.0$ and it $0.050 \mathrm{~mol} \mathrm{~L}^{-1}$. However, the kind of phenol extractor was not statistically important. The best results for selective catechol oxidation were obtained by using the multivariate technique. In this way, the multivariate methodology is indicated to increase the performance of the crude extract in the selective oxidation reactions.

Keywords: homogeneous enzymatic catalysis, jackfruit, phenol oxidations, factorial designs

\section{Introduction}

Recently, an increasing trend has been observed in the use of new biocatalytic materials in place of pure enzymes, for the development of several different research lines, especially those related to the development of biosensors ${ }^{1}$ and enzyme-catalyzed methods of analysis. ${ }^{2}$ The use of such materials offers some advantages with regard to those procedures based on the use of pure and isolated enzymes, especially by providing a better lifetime and lower cost. ${ }^{3,4}$

Natural and undesirable browning reactions, using atmospheric oxygen as oxidant, occur by the catalysis of,

\footnotetext{
* e-mail: cestari@ufs.br
}

mainly, the enzyme polyphenol oxidase (PPO) ${ }^{3-5} \mathrm{PPO}$ is a copper-containing oxidase having catecholase and/or cresolase activity. PPO catalyses o-hydroxylation of monophenols to give o-diphenols (cresolase activity) and o-diphenols to o-quinones (catecholase activity). For PPOs isolated from a great number of fruits and vegetables, there exist different substrate specificities, degrees of inhibition while its level in plants is dependent on the species, cultivar, maturity and age. In general, the PPO activity is very low in young plants, often undetectable. ${ }^{1}$

PPO is mainly responsible for catalyzing the browning reaction through the phylogenetic scale, undesirable in food technology because of the unpleasant appearance and the concomitant development of off-flavors. Among 
the most common studies on PPO are those concerning inhibition using sulfur compounds, ${ }^{6-8}$ carboxylic acids, ${ }^{9}$ halide salts, ${ }^{10}$ microwave radiation ${ }^{11}$ and so on. Techniques such as dynamic electron paramagnetic resonance (EPR) and Raman resonance have pointed to an interaction between substrates and the inhibitory agents with copper at the active site of PPO. ${ }^{1}$ However, proposed theories on enzymatic catecholase and cresolase mechanisms, as well as the oxidation state of the copper atom, are still controversial. ${ }^{1}$

Extraction of high activity PPO is desirable, since this enzyme is important in analytical methods for total phenol content determinations in several biological and pharmaceutical samples, such as hydroquinone in cosmetic creams and photographic developers and paracetamol in pharmaceutical formulations. ${ }^{1,3,4,12-16}$

The purpose of this paper is to describe the performance of Jackfruit crude extracts, a new and relatively unexplored enzymatic source, in homogeneous phase phenol oxidation reactions, using atmospheric oxygen as oxidizing agent. The factors considered are $\mathrm{pH}$, concentration of the phosphate buffer and the kind identity of some commercially available biophenols extractors. Initially, only conventional univariate procedures are considered.

More specific data allows the evaluation not only of the isolated factor effects, but also possible synergistic and antagonistic interaction effects involving two or even more factors on the enzyme activity. Specifically, a factorial design ${ }^{17,18}$ adequate to study the three factors mentioned has been carried out. This factorial design requires the execution of only a few distinct experiments. In order to determine the statistical significance of the evaluated effects, isolated duplicate determinations were made for each experiment.

\section{Experimental}

Jackfruits (Artocarpus integrifolia) were harvest from the Brazilian northeastern region. All chemicals were analytical grade from Aldrich and used without purification. Enzyme assays were conducted using a Micronal UV-Vis spectrophotometer at $25^{\circ} \mathrm{C}$.

\section{Obtention of the PPO-containing crude extract}

For preparing the crude extract, $25 \mathrm{~g}$ of the fruit was homogenized in $100 \mathrm{~mL}$ of phosphate buffer containing $2.5 \mathrm{~g}$ of the biophenol extractor polyvinylpyrrolidone (PVP) during $40 \mathrm{~s}$. After fruit filtration, the crude extract was centrifuged at $30000 \mathrm{rpm}$ during $40 \mathrm{~min}$ at $4{ }^{\circ} \mathrm{C}$ and kept in a refrigerator at this same temperature. The $\mathrm{pH}$ of the buffer, its concentration and the kinds of biophenol extractor were tested in distinct experiments, as previously described. ${ }^{3,4}$

\section{Assay of PPO activity}

Enzyme activity was determined measuring the increase in absorbance at $410 \mathrm{~nm}$ owing to the formation of the respective quinone for each substrate studied. ${ }^{3,4,7,21}$ Blank tests containing only $3.0 \mathrm{~mL}$ of substrate solution or the buffer solution did not provide any catalytic effect. A typical reaction ${ }^{3,4,7,8}$ was carried out by mixing of $2.8 \mathrm{~mL}$ of the selected substrate and $0.20 \mathrm{~mL}$ of the crude extract in a quartz cuvette. The reaction was started by addition of the enzyme present in the crude extract. Enzyme activity (At) was calculated from the initial lag period of the curve of absorbance versus reaction time, by using the expression: ${ }^{13,4,7,8}$

$$
A t=\frac{1000 \Delta_{a b s}}{V x \Delta t}
$$

where $\mathrm{V}$ is the volume of the buffer plus the crude extract $(3.0 \mathrm{~mL}), \Delta \mathrm{t}$ is the variation of the time assayed in the lag period and $\Delta_{\text {abs }}$ is the variation of the absorbance of the solution in the reaction time considered.

One unit of polyphenol oxidase activity is defined as the amount of enzyme that causes an increase of 0.001 in absorbance per min under the conditions described.

\section{Effect of $\mathrm{pH}$}

The activity of the enzyme was determined in a $\mathrm{pH}$ range of 4.0 to 8.0 using 0.050 to $0.40 \mathrm{~mol} \mathrm{~L}^{-1}$ phosphate buffer and catechol as substrate. ${ }^{18,19}$ The $\mathrm{pH}$ values of 4 and 5 and their respective phosphate concentrations were used in the factorial design study, in order to compare the results to other PPO oxidation performances. ${ }^{3,4,17,18}$

\section{Effect of the biophenol extractor}

In order to determine the effect of the kind of biophenol extractant, the crude Jackfruit extraction was carried out using the PVP polymer (Polyclar) due to its good stability, facility for separation, using simple filtration operations, and also since it works as good biophenol extraction performance, as reported earlier. ${ }^{3,4}$ Four PVP commercial denominations were evaluated (SB-100, Super-R, R-10 and $\mathrm{FJ}$, all free gifts from ISP Technologies Inc $\left(\mathrm{FTIR}=1654 \mathrm{~cm}^{-1}\right.$, 
$v(\mathrm{C}=\mathrm{O}$ from amide $) ; 1458 \mathrm{~cm}^{-1}, v\left(\mathrm{C}-\mathrm{H}\right.$ from $\left.\mathrm{CH}_{2}\right) ; 732 \mathrm{~cm}^{-1}$, $\delta\left(\mathrm{C}-\mathrm{H}\right.$ from $\left.\left.\mathrm{CH}_{2}\right)\right)$. The main differences among the polymers concerns the granulometry of each polymer type. Information on the extraction performance using this important kind of polymer was noted only for the univariated procedures, ${ }^{3,4}$ but more specific data, using multivariate methodologies, have not yet been reported. A systematic study with each PVP sample is necessary in order to establish the best biophenol extractant. Initially, a univariate study with the PVP samples was done. After this, the worst and the best samples in the oxidation reactions performance were used in the factorial design.

\section{Factorial design study}

A $2^{3}$ full factorial design with the factors and levels presented in Table 1, was performed with the aim of determining the importance of selected experimental parameters used in the univariate assays.

Table 1. Factors and levels used in the factorial design

\begin{tabular}{lcc}
\hline Factors & \multicolumn{2}{c}{ Levels } \\
& $(-)$ & $(+)$ \\
\hline 1. $\mathrm{pH}$ buffer & 4.0 & 5.0 \\
2. Polyclar & Super-R & $\mathrm{SB}-100$ \\
3. Buffer concentration $/ \mathrm{mol} \mathrm{L}^{-1}$ & 0.050 & 0.10 \\
\hline
\end{tabular}

The success of a factorial design depends, in part, on the range of the factors investigated. One must choose differences in levels that are large enough to give changes in the response larger than experimental error. However, these differences should not be larger than quadratic or higher order effects, due to the individual factors which might invalidate the factorial model. ${ }^{17,20}$

\section{Results and Discussion}

The Jackfruit crude extract was used in oxidizing reactions with selected substrates. The choice of this fruit was due mainly to its uncolored crude extract after its partial purification by centrifugation. In addition to this, the fruit is a relatively unexplored enzymatic source for catalytic and analytical purposes, and presents good stability up to about two-three months of stockage. This fruit browns after exposition to air and can be found easily in Brazil.

\section{Univariate studies}

The activity of PPO using the substrates o-, $\mathrm{m}$ - and pcresols, pyrogallol and catechol are 30, 30, 30, 70 and
$6000 \mathrm{U} \mathrm{mL}^{-1}$, respectively . As it can be noted, catechol presented the best quantitative quinone formation, as also indicated in other investigations. ${ }^{19,21}$ In this way, Jackfruit crude extract presented excellent selectivity for catechol and this substrate was used in both the univariate and factorial studies.

The $\mathrm{pH}$ dependence study for catecholase activity is presented in Figure 1. The $\mathrm{pH}$ profile was determined between 4.0 to 8.0. Only one maximum at $\mathrm{pH} 5.0$ was observed within the $\mathrm{pH}$ range used. In general, PPOs showed maximum activity at or near neutral $\mathrm{pH}$ values ${ }^{1}$. However, the optimum $\mathrm{pH}$ has been found to vary with the enzymatic source and the substrate over a relatively wide range of values, ${ }^{22}$ including in alkaline medium. ${ }^{21}$ The best phosphate buffer concentration was $0.10 \mathrm{~mol} \mathrm{~L}^{-1}$, as indicated in Figure 2.

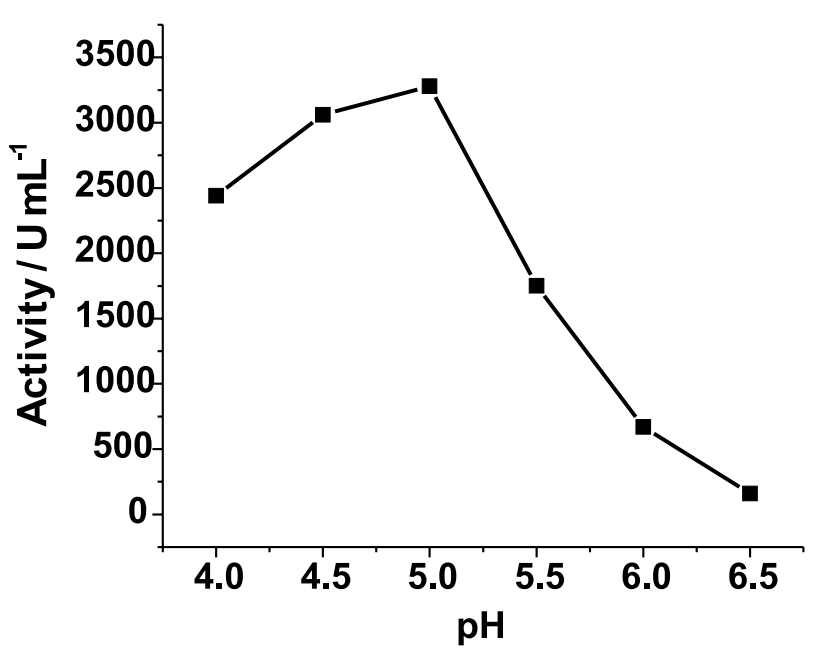

Figure 1. Variation of catecholase activity of the crude extract as a function of $\mathrm{pH}$ in phosphate buffer

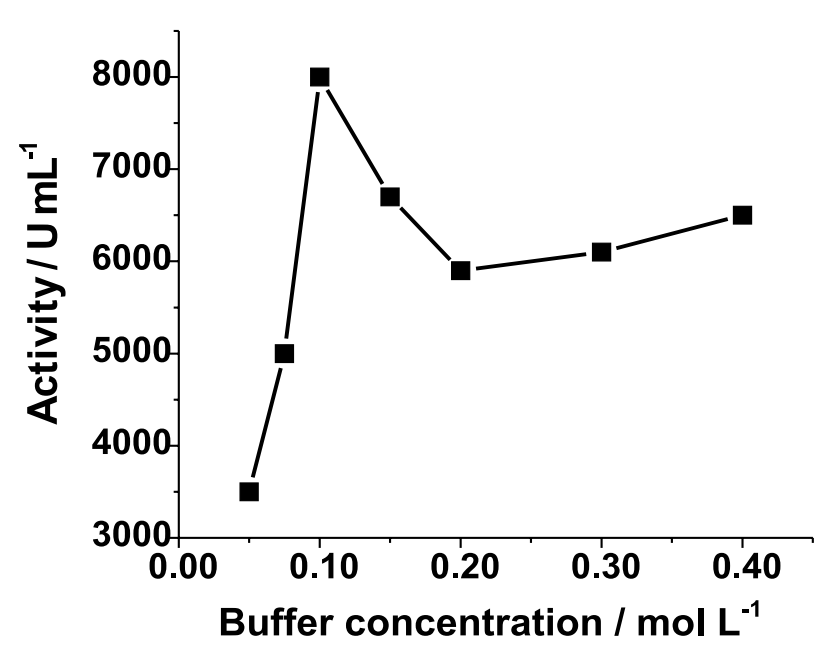

Figure 2. Catecholase activity of the enzymes on the crude extract as a function of phosphate buffer concentration, in a $\mathrm{pH}$ value of 5.0 
Table 2. Factorial design with a generator function $\mathrm{I}=123 . \mathrm{A}(1)$ and $\mathrm{A}(2)$ represent the duplicates for the enzymatic activity $\left(\mathrm{U} \mathrm{mL}^{-1}\right)$ under the same experimental conditions $\mathrm{A}(\mathrm{m})$ are the average values in $\mathrm{U} \mathrm{mL}^{-1}$ and the relative percentage (\%)

\begin{tabular}{cccccccc}
\hline Experiment & Factor 1 & Factor 2 & Factor 3 & $\mathrm{~A}(1)\left(\mathrm{U} \mathrm{mL}^{-1}\right)$ & $\mathrm{A}(2)\left(\mathrm{U} \mathrm{mL}^{-1}\right)$ & $\mathrm{A}(\mathrm{m})(\mathrm{U} \mathrm{mL}-1)$ & $\mathrm{A}(\mathrm{m})(\%)$ \\
\hline 1 & - & - & - & 4620 & 4980 & 4800 & 72.1 \\
2 & + & - & - & 6780 & 6540 & 6660 & 100.0 \\
3 & - & + & - & 4680 & 4440 & 4560 & 68.5 \\
4 & + & + & - & 6270 & 6090 & 6180 & 92.8 \\
5 & - & - & + & 3300 & 3030 & 3165 & 47.5 \\
6 & + & - & + & 5190 & 5640 & 5415 & 81.3 \\
7 & - & + & + & 810 & 660 & 735 & 11.1 \\
8 & + & + & + & 6210 & 5700 & 5955 & 89.4 \\
\hline
\end{tabular}

In order to prevent undesirable reactions between the natural phenols and PPO, quantitative extraction of plant phenols can be made using water-insoluble PVP, which can extract biophenols by a well-postulated hydrogen bonding of the ionizable hydrogens of the plant phenol to oxygens of the polyvinylpyrrolidone. ${ }^{23}$ In univariate studies, the results show activities of $6100,7300,7650$ and $8000 \mathrm{U} \mathrm{mL}^{-1}$ for the PVPs noted as Super-R, P-10, FJ and SB-100, respectively. In conclusion, by using the SB100 PVP, the catecholase activity was maximized.

\section{Multivariate studies}

The results for preliminary univariate studies for catechol oxidation were used in the factorial design, as shown in Table 1, in order to identify significant results for principal and interactive effects. ${ }^{17,24}$

The principal and interactive effects $\left(\mathrm{E}_{\mathrm{f}(\mathrm{i})}\right)$ of the factors on the PPO activity can be calculated from the results in Table 2, using the following equation: ${ }^{17,24,25}$

$$
E_{f(i)}=\bar{R}_{+, i}-\bar{R}_{-, i}
$$

where $R_{+, i}$ and $R_{-, i}$ are average values of the enzymatic activity for the high (+) and low (-) levels of each of the three factors $i=1-3$. Since independent duplicate experiments were performed as indicated in Table 2, standard error for principal and interactive effect values (E) can be calculated as follows: $:^{17,20}$

$$
E=\left\{\Sigma\left(d_{i}\right)^{2} / 8 N\right\}^{1 / 2}
$$

The results calculated for all principal and interactive effects are presented in Table 3.

PPO activity values, found by factorial design, can be most conveniently viewed in Figure 3, where the values are presented at the vertices of a cube, with each side of the cube corresponding to one of the three factors evaluated, having the enzymatic activity in terms of the relative percentage of catechol oxidation.
Table 3. Principal and interaction effect values for the factorial design

\begin{tabular}{lrr}
\hline Calculated effects & $\begin{array}{c}\text { Values effects } \\
\left(\mathbf{U} \mathbf{~ m L}^{-1}\right)\end{array}$ & $\begin{array}{c}\text { Values effects } \\
(\boldsymbol{\%})\end{array}$ \\
\hline Principal & & \\
1. pH & $2737 \pm 300$ & $41.1 \pm 4.5$ \\
2. Polyclar & $-652 \pm 300$ & $-9.8 \pm 4.5$ \\
3. Buffer concentration & $-1732 \pm 300$ & $-26.0 \pm 4.5$ \\
Interactions & & \\
$1-2$ & $683 \pm 300$ & $10.3 \pm 4.5$ \\
$1-3$ & $998 \pm 300$ & $15.0 \pm 4.5$ \\
$2-3$ & $-1380 \pm 300$ & $-20.7 \pm 4.5$ \\
$1-2-3$ & $802 \pm 300$ & $12.0 \pm 4.5$ \\
\hline
\end{tabular}

Differences in enzymatic performance can also be evaluated by observing different lag periods on absorbance versus reaction time plots, used to calculate the enzyme activity. ${ }^{13,4}$ Pronounced alterations were also found in the factorial design results, in relation to the maximum absorbance values, varying significatively from 0.775 to 1.022 units (data not shown). These data confirm alterations in the enzymatic catalytic performance, but this can be better evaluated using the factorial design approach. In general, the absorbance reached constant values, for each experimental factorial design experiment, at the end of 300 seconds (data not shown).

The results observed in Table 2 reveal that PPO activity is significatively affected by the changes proposed, given by (-) and (+) levels. The activity values at the vertices of the upper plane of the cube are, on average, larger than those of the lower plane. This is a clear evidence of the $\mathrm{pH}$ effect and confirms definitively the importance of $\mathrm{pH}$. The optimum $\mathrm{pH}$ varies with the source of enzyme and also depends on the phenolic substrate chosen for the assay, 2,25,26 but it can also be affected by the type of buffer and the purity of the enzyme. ${ }^{1}$

The observed antagonistic principal effect for the kind of PVP results from the best extraction conditions at low $\mathrm{pH}$ values, near to 4.0, where the hydrogen bonding PVPbiophenols are maximized. ${ }^{1}$ Differences in the kind of the 
PVP samples seem not to be sufficient to significatively change the PPO activity, since the chemical structures for all PVP samples, obviously, are the same.

The buffer concentration variable works to significatively decrease the PPO activity. Inhibitory studies showed that the enzyme can be partially inactivated when in contact with certain ions in high concentrations. ${ }^{27}$ This is strongly suggested by computer simulation studies, leading to proposed protonated enzyme-substrate complexes. ${ }^{19}$ Inhibition involves an action of anionic ions on the copper atom of the active site. The inhibitory effect was reported to be $\mathrm{pH}$-dependent where inhibition increased with a decrease in $\mathrm{pH}$ value, with maximum inhibition occurring in the 3.5 to $4.0 \mathrm{pH}$ range. ${ }^{1}$ It has been suggested that $\mathrm{pH}$ values, affect the interactions between the positive charge on an imidazole functional group, located at the active site and the negatively charged on anionic group, such as the phosphate of the buffer. ${ }^{19}$ Intrinsic enzyme parameters are strongly affected, where the initial lag on the kinetic curves is large and the $\mathrm{V}_{\max }$ decreases when the electrolyte concentrations are high.

Inspection of the values in Figure 3 reveals that the dependence of the enzyme activity on the factors studied is much more complicated than can be described by univariate studies and factorial design principal effects alone. This complex behavior is indicated by the large absolute Polyclar type and the buffer concentration interactive values.

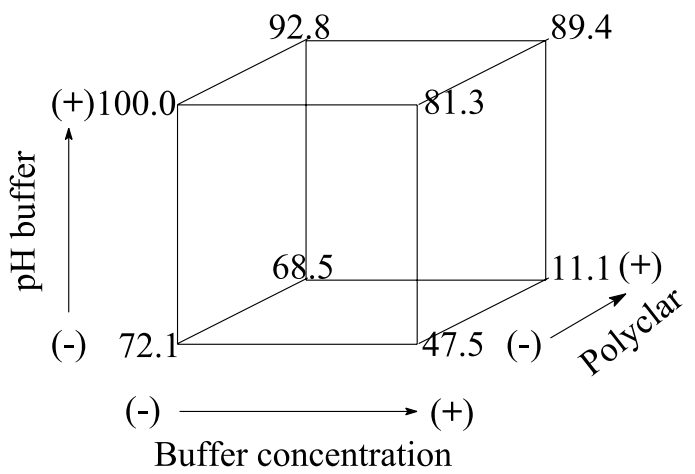

Figure 3. Relative percentage (\%) results of the catecholase activity (vertices of the cube) of enzymes on the crude extract due to different levels of the $\mathrm{pH}$, Polyclar and buffer concentration (sides of the cube) in the $2^{3}$ factorial design

Univariate studies indicated that (+) level values provide high enzyme activity. Surprisingly, principal and interactive effect for Polyclar and buffer concentration are all antagonistic and decrease PPO activity. In a similar manner, interaction of $\mathrm{pH}$ - Polyclar is also antagonistic. However, Polyclar-buffer concentration interactions present a higher magnitude of interaction than the ones for $\mathrm{pH}$-Polyclar and $\mathrm{pH}$-buffer concentration interactions. This is probably due to the high $\mathrm{pH}$ effect that can decrease the magnitude of these antagonistic effects. The complex dependence of the PPO activity can also be noted by the relatively uncommon, but significative, three factors of interactions.

\section{Conclusions}

This study shows that Jackfruit crude extract exhibits a very selective catecholase behavior in oxidative reactions. The fruit may contain different classes of phenols with different susceptibilities to enzymatic oxidation. However, when the reactions were carried out using oxygen as oxidizing agent, the main catalytic contribution seems to be for the PPO enzyme, as shown also by the excellent selectivity for catechol. This fact is also confirmed by other investigations. ${ }^{1,3,4,8,13}$ A factorial design can provide new and efficient approaches to study enzymatic performance by an investigation of simultaneous changes in some selected experimental factors. The values of the several effects show that $\mathrm{pH}$ has a decisive influence on PPO activity. PPO is sensitive to an increase in the ionic strength, where the activity is low at high buffer concentration. However, this effect, as well as the effect of the kind of Polyclar, are not observed in the univariate studies.

The main importance of the factorial design is to reveal the real effect of each factor studied and their interactions. The present investigation reveals that these interactions are very important and strongly affect the PPO activity. Univariate procedures, often used in studies involving the performance of several enzymes, are not capable of recognizing these important interactive effects., ${ }^{4,17,20,24,25}$ Despite the best univariate results for SB-100, the kind of Polyclar seems not to have significant importance for PPOcatalyzed reactions. Additional information on the interaction PVP-enzymes can be found by specific references in this field. ${ }^{28,29}$ Evaluation of the experimental factors in enzymatic catalysis using only univariate procedures does not seem to be adequate.

Other studies involving Jackfruit crude extracts such as its inhibition in selective oxidation reactions, as well as the kinetic parameters obtained are in progress in our laboratory.

\section{Acknowledgments}

The authors thank CNPq for fellowships to A.J.P.N. and C.A. and ISP Technologies Inc. for the Polyclar samples. We are grateful to EMBRAPA / SERGIPE - BRAZIL, Dr. O. 
Fatibello-Filho and Dr. I. V. Cruz for technological support, and Dr. R. E. Bruns for suggestions and discussions on the factorial design study.

\section{References}

1. Zawistowski, J.; Biliaderis, C.G.; Eskin, N.A.M. In Oxidative Enzymes in Foods; Robinson, D.S.; Eskin, N.A.M.; eds.; Elsevier Publishers: New York, 1995, p. 217.

2. Robert, C.; Rouch, C.; Richard-Forget, F.; Pabion, M.; Cadet, F.; Plant Physiol.Biochem. 1996, 34, 369.

3. Vieira, I.C.; Fatibello-Filho, O.; Anal. Lett. 1997, 30, 895.

4. Vieira, I.C.; Fatibello-Filho, O.; Anal. Chim. Acta 1998, 366, 111.

5. Rescigno, A.; Sanjusti, E.; Pedullian, G.F.; Valgimigli, L.; Anal. Lett. 1999, 32, 2007.

6. Ricquebourg, S.L.; Robert-da Silva, C.M.-F.; Rouch, C.C.; Cadet, F.R.; J. Agric. Food Chem. 1996, 44, 3457.

7. Robert, C.; Cadet, F.; Biochem. Educ. 1996, 24, 157.

8. Robert, C.; Richard-Forget, F.; Rouch, C.; Pabion, M.; Cadet, F.; Int. J. Biochem. Cell Biol. 1996, 28, 457.

9. Robert, C.; Rouch, C.; Cadet, F.; Food Chem. 1997, 59, 355.

10. Robert, C.; Rouch, C.; Cadet, F.; J. Enzyme Inhib. 1998, 13, 285.

11. Rodríguez-López, J.N.; Fenoll, L.G.; Tudela, J.; Devece, C.; Sanchéz-Hernández, D.; de los Reyes, E.; García-Cánovas, F.; J. Agric. Food Chem. 1999, 47, 3028.

12. Burton, S. G.; Boshoff, A.; Edwards, W.; Rose, P. D.; J. Mol. Catal., A 1998, 5, 411.

13. Edwards, W.; Bownes, R.; Leukes, W.D.; Jacobs, E.P.; Sanderson, R.; Rose, P.D.; Burton, S.G.; Enzyme Microb. Technol. 1999, 24, 209.
14. Hipólito-Moreno, A.; León-González, M.E.; Pérez-Arribas, L.V.; Polo-Díez, L.M.; Anal. Chim. Acta 1998, 362, 187.

15. Russel, I.M.; Burton, S.G.; Anal. Chim. Acta 1999, 389, 161.

16. Zachariah, K.; Mottola, H.; Anal. Lett. 1989, 22,1145.

17. Box, G. P. G.; Hunter, W.G.; Hunter, J. S. In Statistics for Experimenters: An Introduction for Design, Data Analysis and Model Building; John Wiley \& Sons: New York, 1978, p. 157.

18. Lindberg, R.; Sundholm, G.; Pettersen, B.; Sjoeblom, J.; Friberg, S.E.; Colloids Surf., A 1997, 123-124, 549.

19. Valero, E.; García-Carmona, F.; J. Agric. Food Chem. 1998, 46, 2447.

20. Barros Neto, B.; Scarminio, I.S.; Bruns, R. E. In Planejamento e Otimização de Experimentos; Editora da Unicamp: Campinas, Brazil, 1995, p. 61.

21. Arslan, O.; Temur, A.; Tozlu, I.; J. Agric. Food Chem. 1998, 46, 1239.

22. Robert, C.M.; Cadet, F.R.; Rouch, C.C.; Pabion, M.; RichardForget, F.; J. Agric. Food Chem. 1995, 43, 1143.

23. Andersen, R.A.; Sowers, J.A.; Phytochemistry 1968, 7, 293.

24. Cestari, A.R.; Bruns, R.E.; Airoldi, C.; Colloids Surf., A 1996, $117,7$.

25. Cestari, A.R.; Vieira, E.F.S.; Bruns, R.E.; Airoldi, C.; J. Colloid Interface Sci. 2000, 127, 66.

26. Zhang, X.; Flurkey, W.H.; J. Food Biochem. 1999, 23, 95.

27. Krajewska, B; Zaborska, W.; J. Mol. Catal., A 1999, 6, 75.

28. Doner, L.W.; Bécard, G.; Irwin, P.L.; J. Agric. Food Chem. 1993, 41, 753.

29. McMurrough, I.; Madigan, D.; Smith, M.R.; J. Agric. Food Chem. 1995, 43, 2687.

Received: December 22, 2000

Published on the web: March 12, 2002

FAPESP helped in meeting the publication costs of this article. 